\title{
MOBILE EMERGENCY MEDICAL SERVICES IN THE PSYCHOLOGICAL CRISIS AND THE PSYCHOSOCIAL PARADIGM ${ }^{1}$
}

\author{
Alexsandro Barreto Almeida², Eliane Regina Pereira do Nascimento ${ }^{3}$ Jeferson Rodrigues ${ }^{4}$, Maria Terezinha \\ Zeferino $^{5}$, Ana Izabel Jatobá de Souza ${ }^{6}$, Patrícia Madalena Vieira Hermida
}

${ }^{1}$ This article is part of the thesis - Pre-hospital care to the subject in psychic crisis, presented to the Programa de Pós-Graduação em Enfermagem, Universidade Federal de Santa Catarina (UFSC), in 2011.

${ }^{2}$ M.Sc. in Nursing. Coordinator of the Curso de Enfermagem, Faculdade Juscelino Kubitschek. Brasilia, Distrito Federal, Brazil. E-mail: alexsandro@facik.com.br

${ }^{3}$ Ph.D. in Nursing. Associate Professor, Departamento de Enfermagem, UFSC. Florianópolis, Santa Catarina, Brazil. E-mail: eliane. nascimento@ufsc.br

${ }^{4}$ Ph.D. in Nursing. Professor, Departamento de Enfermagem, UFSC. Florianópolis, Santa Catarina, Brazil. E-mail: jef_rod@hotmail. com

${ }^{5}$ Ph.D. in Nursing. Assistant Professor, Departamento de Enfermagem, UFSC. Florianópolis, Santa Catarina, Brazil. E-mail: tzeferino@hotmail.com

${ }^{6}$ Ph.D. in Nursing. Assistant Professor, Departamento de Enfermagem, UFSC. Florianópolis, Santa Catarina, Brazil. E-mail: aijsenf@ gmail.com

7 Doctoral student, Programa de Pós-Graduação em Enfermagem, UFSC. Florianópolis, Santa Catarina, Brazil, E-mail: patymadale@ yahoo.com.br

\begin{abstract}
The objective was to know the perception and interventions of basic support teams of the mobile emergency medical service in a situation of psychic crisis. This was a qualitative and descriptive research study conducted in the state of Santa Catarina, with four professional teams of the Basic Support Units in Mobile and Emergency Service. The data were collected from April to June of 2011, through semi-structured interviews. Collective Subject Discourse was used to organize and analyze data and to discuss the Psychosocial Paradigm. From the results, three discourses emerged with the main ideas: crisis behavior disorder and psychological instability; hallucinations and aggressiveness; intervention with physical or pharmacological restraint and referral. It is concluded that the concept of crisis is linked by professionals to the positivism of psychiatry, and pre-hospital care follows protocol measures in attending the person in mental crisis, far from the principles determined by the psychosocial paradigm.
\end{abstract}

DESCRIPTORS: Mental health. Crisis. Psychiatry. Emergency. Nursing.

\section{ATENDIMENTO MÓVEL DE URGÊNCIA NA CRISE PSÍQUICA E O PARADIGMA PSICOSSOCIAL}

\begin{abstract}
RESUMO: Objetivou-se conhecer a percepção e as intervenções de equipes de suporte básico do serviço de atendimento móvel de urgência na situação da crise psíquica. Estudo de abordagem qualitativa, descritiva, realizada em Santa Catarina, com quatro equipes de unidades de suporte básico do serviço de atendimento móvel de urgência. Os dados foram coletados de abril a junho de 2011, mediante entrevista semiestruturada. Utilizou-se para a organização e análise dos dados o Discurso do Sujeito Coletivo e para a discussão, o paradigma psicossocial. Dos resultados emergiram três discursos com as Ideias Centrais: crise como alteração de comportamento e instabilidade psicológica; manifestação com presença de alucinações e agressividade; intervenção que ocorre com contenção física, medicamentosa e encaminhamento. Concluiu-se que a concepção de crise pelos profissionais está atrelada ao positivismo da psiquiatria e a atenção pré-hospitalar segue medidas protocolares no atendimento à pessoa em crise psíquica, distantes dos princípios determinados pelo paradigma psicossocial.
\end{abstract}

DESCRITORES: Saúde mental. Crise. Psiquiatria. Urgência. Enfermagem.

\section{ATENDIMIENTO MÓVIL DE URGENCIAS EN CRISIS PSÍQUICAS Y EL PARADIGMA PSICOSOCIAL}

RESUMEN: Este estudio tuvo como objetivo conocer la percepción y las intervenciones de equipos de apoyo básicos del centro de salud móvil de emergencia en el estado de crisis psíquica. Investigación cualitativa, descriptiva realizada en el estado de Santa Catarina con profesionales de cuatro equipos de Unidades de Soporte Básico del Servicio de Atención Móvil de Urgencias. Los datos fueron recolectados de abril a junio de 2011 mediante entrevista semiestructurada. Se utilizó el Discurso del Sujeto Colectivo para organizar y analizar los datos y para la discusión el Paradigma Psicosocial. De los resultados emergieron tres discursos con las ideas: crisis como alteración del comportamiento e inestabilidad psicológica; se manifiesta con alucinaciones y agresividad; la intervención surge con contención física, medicamentosa e interconsultas. Se concluye que la concepción de la crisis por los profesionales está ligada al positivismo de la psiquiatría y la atención pre-hospitalaria sigue medidas protocolares en el atendimiento a la persona en crisis psíquica, distante de los principios determinados por el paradigma psicosocial.

DESCRIPTORES: Salud mental. Crisis. Psiquiatría. Urgencias. Enfermería. 


\section{INTRODUCTION}

The Mobile Emergency Medical Services (SAMU) in Brazil is a point of care that integrates the urgency and emergency network (RUE) and the Psychosocial Care Network (RAPS). Ordinance no. 2048/GM of 05 November 2002..$^{-2}$ regulates this service that includes the psychiatric emergency care as one of its assignments.

The psychic crisis lies at the condition of urgency and, according to the resolution of the Federal Council of Medicine, ${ }^{3}$ urgency is the occurrence of an unexpected health problem, potentially or non life-threatening, in which the person needs immediate medical care. Psychosis, attempted suicide, depression and organic brain syndromes are included as psychiatric emergencies. ${ }^{1}$

One study ${ }^{4}$ showed that the major symptom in psychiatric urgency is psychomotor agitation, whose cause is associated with substance abuse or clinical conditions that aggravate psychological distress.

A European study showed that psychiatric emergencies account for rates of $3.7 \%$ of the total of care provided. ${ }^{5}$ In Brazil, studies report rates of $2.4 \%,{ }^{6} 2.98 \%, 75.2 \%,{ }^{8}$ and $8.9 \%,{ }^{9}$ of psychiatric emergency care in all pre-hospital care syndromes.

In the technical legal scope, ${ }^{1-2}$ SAMU must perform treatments in psychiatric urgencies in order to accompany the users in crisis to a service in the urgency and emergency network. This procedure is performed by the basic support units (USB) with teams composed of drivers and nursing assistants who perform non-invasive supportive measures, corresponding to the initial approach of the person, as well as basic care of ventilation and circulation, immobilization, and transportation to emergency services. Another transport and support device is the advanced support unit (USA) whose teams are composed of drivers, nurses and physicians that perform invasive procedures for ventilatory and cardiovascular support, and perform the transport of patients between hospitals. ${ }^{7}$ However, attendance to the person in psychic crisis is handled by the basic support.

However, the guidelines for operation of the SAMU do not specify the content of professional training. This opens the space for perpetuation of positivist psychiatry, as well as physical and chemical restraint practices and transport to the hospital being the only intervention possibilities in mental crises. ${ }^{10}$
Therefore, the crisis needs to be understood as an individual manifestation that is developed in the collective space with all the inconsistencies and contradictions resulting from its social and historical construction. In addition, the care provided in these situations needs to maintain social, environmental and emotional ties to the subjects, avoiding violent, repressive and exclusive measures that can compromise the relationship of patients in crisis. ${ }^{10}$

With the National Policy on Mental Health, approved in 2001, the country began the process of change in mental health, being guided by the psychosocial paradigm, which prioritizes the community and territorialized services. This new form of mental health care, based on psychosocial care, requires reflection and the creation of concepts and practices of innovative care. ${ }^{11}$

The psychosocial paradigm assumes that the professional approximates the person's life context, clinical and mental state evaluation, to favor the manifestation of suffering. It is crucial to recognize the person in crisis as a singular, complex being surrounded by a family and social network. ${ }^{11}$

In this sense, studies on the subject indicate that, in crisis, the consolidation of an intervention, more articulated with Brazilian psychiatric reform, requires the implementation of measures such as job training. ${ }^{10}$

Thus, this study had as a question: how do the professionals of a basic life support service perceive the psychological crisis, and intervene in the moment of crisis? Thus, this research aimed to identify the perceptions and the interventions of basic support teams of Mobile Emergency Medical Services in mental crisis situations.

\section{METHOD}

This was a qualitative, exploratory and descriptive study, performed with four professional teams of USB - SAMU, in the municipality of Santa Catarina. The inclusion criteria established was: professionals caring for a person in mental crisis who were working during the period of the data collection. These criteria were met by 14 professionals, and of these, seven were nursing technicians and seven were rescuers acting as drivers and in assistance.

Data collection was conducted from April to June of 2011, after approval by the Ethics Com- 
mittee of the Universidade Federal de Santa Catarina (Protocol n. 1060/11), and signatures were obtained on the Terms of Free and Informed Consent. Data were collected using semi-structured interviews that were recorded and later transcribed. The anonymity of participants was preserved, by adopting for their identification the initial P (Professional), followed by the number corresponding to the sequence of interviews.

Participants were asked how they perceived the psychological crisis and the assistance given by SAMU to the person in crisis. For the process of organization and analysis of the data, the Discourse of the Collective Subject (DSC) ${ }^{12}$ technique was used, corresponding to a discourse synthesis, elaborated with pieces of individual discourses in a similar way, using the first singular person. Three methodological figures were adopted of the DSC: key expression (KE), central idea (CI) and the DSC. The KE are individual discourse excerpts, highlighted by the researcher, and describe the essence of the content of the discourse. The CIs are names or linguistic expressions that describe and name, as concisely and accurately as possible, the meaning(s) of the homogeneous set of KE, which constitute the DSC. ${ }^{12}$

In order to construct the DSCs, the steps followed were: careful reading of each interview; grouping of statements related to each question; highlights of CIs of each statement; grouping of similar or complementary CIs; identification of $\mathrm{KE}$ of the individual statements; and grouping of the KEs according to CIs that defined them. These clusters of KEs with the same CI constituted the DSCs.

The discourses were analyzed based on the psychosocial paradigm that consists in seeking health care, by means of dialogue between the different disciplines and perceptions of the world. It is a type of health production focused on the subject who is suffering, considering the socio-political dimension of the suffering and the complexity of its unique factors, such as the implication of the subject of suffering before treatment and his integration into the institution. ${ }^{13}$

\section{RESULTS AND DISCUSSION}

From the testimony of participants, three DSCs emerged, which presented the themes: understanding of the psychological crisis; characteristics of psychological crisis situations; interventions for the individual in psychological crisis.
Each theme is related to a CI. For this presentation, it was decided not to present the KEs of individual discourses, since they are inserted in the DCS, represented by DSC1, DSC2, and DSC 3 for differentiation.

The DCS 1 represents the discourse of ten participants, DCS2 corresponds to the discourse of 13 participants, and DCS3 corresponds to that of 14 participants.

The first discourse refers to the understanding of the psychological crisis, characterized as a disease that alters the behavior of the subjects in a way that prevents social interaction.

\section{Theme 1 - Understanding of the psychological crisis}

\section{1 - Change of behavior, psychological instability, mental illness}

DSC 1 - Psychiatric disorders alter the balance of the person, causing discernment and behavioral changes. It is everything that is not normal, with a psychological or neurological instability, due to not having a proper mind and logical reasoning, It is a disease that is not well seen by all and sometimes excludes people from the social environment. It is caused by an imbalance of itselfdue, sometimes, to a chemical dependency, day-to-day agitation, or a depression that becomes an obsession. I understand that everyone has impaired mental health due to work, financial situation, family situations, interfering in social life. Mental illness rather than only belonging to a psychiatric patient, I believe that it involves the general population, such as depression, emotional difficulties. It is everything that involves the psychic and social parts of the population.

The answer given to a situation depends on how this is conceived. The concept of crisis by the team members of SAMU, present in the DSC 1, reveals a conceptual naturalization linked to the positivism of psychiatry, or even with different trends in psychiatry, such as psychodynamic, phenomenological, epidemiological; the prevailing trend is the model of natural sciences, positivism, which justifies the evidence of medicine. There is a linear explanation of the crisis regarding the disease, when it comes to a contextual and singular phenomenon. Thus, the perception of psychologic crisis influences the observation that the professional of SAMU has on the scenario, since he is an individual who builds the phenomenon and, being part of the scene, their subjectivity also participates. 
The starting point of analysis is to reflect upon the analogy of the crisis considering the double of mental illness. This means that the double of mental illness refers to that which is not inherently being ill but the institutional ways of dealing with the object disease, and not with the person, in which scientific concepts are pre-built. Basaglia's double notion of mental disease is determined by the set of representations diffused in society (stigma, segregation, cultural representations of the disorder), and scientific knowledge (psychiatry, psychoanalysis, psychology, among others) as well as their practices; institutionalization is one of them. ${ }^{14}$

The double crisis means that the discourse situated in professional imagery is anchored in the naturalized conception of the institution, and this removes the possibility of the professional approaching the person in crisis because the association that he makes with the crisis is threatening, misunderstanding, danger, and aggressiveness, among others. Facing this double crisis reveals the deconstruction of human objectification and should be the first therapeutic act, so that the singularity arises in the conceptual constructions of the crisis. ${ }^{14}$

Coming from the double concept of crisis means to question historically institutionalized and institutionalizing knowledge. It is necessary to bracket the crisis to deal with the person. Hussersl's epistemological demarcation ${ }^{14}$ refers to a phenomenon that can be constructed by the observer, based on scientific constructs. Ressignifying the concept of crisis means questioning the epistemological and ontological foundations around the construction of know-how, given the crisis. This assumption evokes a willingness to reach a human dimension, crossed by the border between ideology and science.

Bracketing means to deny the acceptance of a solely theoretical elaboration of traditional psychiatry to account for the crisis and the suffering experience; it means including the person's context as well as symptoms that are attributed labels, ${ }^{14}$ namely, going beyond the classification of symptoms and mechanical assigning of a diagnosis during assessment, reducing to a label all the complexity of life and the person's uniqueness. It means the refusal to accept the positivity of psychiatric knowledge as unique in explaining the crisis. The crisis, in brackets, expresses the epistemic break in the observation of what is not proper to the condition of being in crisis.
The concepts of crisis are social constructions, produced over time and reproduced at the actual moment. One of its common characteristics remains a negative aspect in the eyes of staff and the population in general. ${ }^{15}$

Thus, the concept of crisis is not just a theoretical and paradigmatic construction, but a reconstruction of the life of that which manifests it. However, there is no consensus among the main theoretical currents influencing professional knowledge about the crisis. Positivism refers to it as the worsening of psychiatric symptoms. This is the model that prevails in history in more conventional versions of psychiatry, and that tends to reduce the crisis to a worsening of disease or a disorder and its symptoms, in isolation from the social, cultural, family, community, and existential context.

The theory of crisis can be defined as a destabilization of man's balance in relation to his body and the environment. ${ }^{15}$ The crisis is due to an obstacle to the achievement of important life goals for a period of time, and can become unbearable for a person. ${ }^{16} \mathrm{~A}$ disorganization period arises in which efforts have been made to solve the problem. In essence, the individual is seen as living in a state of emotional balance, aiming always to return to or maintain this state. Thus, the individual solves the problem or adapts to the situation. The crisis would be a circumstance of balance or emotional disturbance, therefore it can lead to the disease. ${ }^{16}$

The crisis is expressed as a "relatively small force, acting for a relatively short period, that can make the whole balance go to one side or the other - to the side of mental health or the mental disorder. During this short period in which the power balance is unstable, a minimal amount of help can mean the difference between a good and a bad outcome". ${ }^{16: 312}$

It should be noted that crisis situations promote a moment of metamorphosis, leaving one known place for another that must be rebuilt due to its new characteristic. ${ }^{15}$ The de-divisions that are necessary sometimes involve the established social impositions, causing chaos in the standards. This perception can be observed in the statement: It's everything that is not normal, with a psychological or neurological instability, due to not having a proper mind and logical reasoning, in other words, unsuitable for living in society. Also, the statement: The person is different from the normal 
state, out of control of logical reasoning, becoming disoriented, doesn't make sense, a discourse consisting of standardization of rules, namely. escaping from the standard requires that the subject is put in an abnormal position. Determining the difference between normal and abnormal moves through the lived moment and the moral concept that has been established, the abnormal being incorrect and thereby stigmatized.

The abnormality represents a break in sociability, which must be rescued by restoring the levels of normality. ${ }^{17}$ This is shown in the process of constitution of the madness stigma, which has historically been guided by the principles of risk, which results in exclusion. With the determination of madness as a disease, treatment is necessary, aimed at full removal of the symptoms. The crisis becomes characterized as an exacerbation of symptoms of the madness disease and, from this, logic should be immediately deleted. This process of stigmatization of the phenomenon of madness relied on the connivance and even support from health care profesisonals. ${ }^{18}$

According to the DCS 1, psychiatric disorders change the person's balance, causing insight and behavioral changes, shows that madness permeates a direct link to danger and a social imagery of exclusion, which is a disease that is not well viewed by all and sometimes excludes people from the social environment, according to the report. Thus, it can be noted that the constitution of the madness phenomenon carries a derogatory and disabling characteristic; therefore health actions are performed by management interventions and are basically corrective.

In order to deconstruct the psychiatric model that has been exclusively based on the disease for over two centuries, an intense discussion among all actors, managers, workers and the society in general is necessary so that a new way of looking at mental health is constructed, one that differs from the disease; a look that prioritizes the subject as a complex and active being throughout the whole process, who is made up of desires and uniqueness, one that breaks with the standard model to understand the madness.

It should be noted that a paradigm shift consists of a continuous and arduous process because it requires the deconstruction of a look that has been instituted for centuries by the society. Therefore, it is necessary to rethink care by creating a meeting space that is capable of producing significant transformations through listening and intervention to the subject in all his complexity. Its fundamental principle is the expansion of the look in the care process with the active participation of those involved, namely. an expanded clinical practice, based on building individual responsibility and stable connections between the health care team and the subject that suffers. ${ }^{19}$

The second discourse contains the characteristics of psychological crises perceived as increased symptoms, identified through disorientation and aggressive behavior.

\section{Theme 2 - Characteristics of psychological crises}

\section{2 - Presence of hallucinations, persecution mania, disorientation, aggressiveness}

DSC 2 - The crisis in mental health is characterized as a transformed person, with the presence of hallucinations, persecution mania, psychosis, suffering from drug use. Psychiatric patients usually go into crisis when they stop taking their medication, but people without a diagnosis also come into crisis as a consequence of stress, causing a derangement to the family. The person is different from the normal state, out of control of logical reasoning, becoming disoriented; not making sense, sometimes he is aggressive, often anxious and tearful. It is an advanced bipolar disorder and schizophrenia disease state.

By reflecting about this discourse, it is questioned: "is it possible to transcribe through symptoms and in terms of disease what motivated the user's demand? Transcribing the demand as a disease, makes the reasons for the demand exist, as symptoms of the disease are functions of the psychiatric evidence and the power of intervention". ${ }^{20: 348}$

It is from this perspective that the professionals in DCS 2 look at the crisis issue, which is determined by the exacerbation of symptoms of psychiatric illness. Another important point is the abnormality of mind and loss of control that make it impossible to live with others, strengthening the social imagery of disability and exclusion of the person in crisis. Society establishes organizational criteria for social interaction, and when these criteria are broken, it is necessary to establish control measures for recovery. It is in this field that there is opportunity for collective learning, in which the SAMU professionals with other professionals 
in the intersectoral network find the possibility of building a response to the crisis based on a unique relationship in the territory. These relationships themselves, in the sociocultural context, are called artisan relationships in dealing with the crisis. ${ }^{21}$

Thus, the transformation of the understanding of the crisis requires a paradigm shift in understanding what is madness in society and especially in healthcare practices, availability of technical staff for welcoming and listening to the subject in crisis, thereby providing a favorable environment for the establishment of a bond.

The statement is an advanced bipolar disorder and schizophrenic disease state, present in the DCS 2 , denotes that the view established by the professionals is based on pathological concepts and especially symptoms, directly related to the principles of biomedical science. With the paradigm shift to understand the phenomenon of madness based on psychosocial care, it is essential to rescue the context of singularity and subjectivity of the subject, because by doing so it is possible to avoid the aggravation of the crisis as well, considering it as a process that generates maturation, growth and self-knowledge. ${ }^{22}$ It is also a time to establish an articulation among the various actors and institutions involved in the mental health network, necessary for the continuing care process. However, it is difficult for health professionals to incorporate these new insights and innovative practices into their daily work to assist in crisis situations, particularly regarding the perception of the possible strengths to be used, due to their uniqueness but also due to lack of knowledge and creativity in building collective actions, and ones that are not stigmatizing.

When it comes to crisis, there is reference not only to an individual experience and not a privilege of people in psychological distress, but also to a complex and global context of situations that interfere with the subject's daily life and his relationship with the world. ${ }^{15}$ In mental health this term is generally used to refer to a specific individual moment in which there are variable questions, emotions, gestures and unique behaviors, which affect the daily life of oneself and those close to them to varying degrees, and are often decisive in terms of demands and interventions in the services. ${ }^{23}$

The DCS 3 contains the interventions in psychological crisis, based on controlling and repressive actions, inconsistent with the psychosocial paradigm.

\section{Theme 3 - Interventions in psychological crisis}

\section{3 - Physical, pharmacological restraint and referral}

DCS 3 - At first it is necessary to assess the scene and investigate whether there is any risk to the team; if there is none, the approach and dialogue with the patient and family is performed in order to review the signs and symptoms and refer to the regulation. When people have this kind of outbreak, they are really confused about reality. Sometimes one has to go into their world to get them to seek a solution to the case. There are outbursts that are so acute and risky, with a knife or a firearm, that police assistance is needed. When he is very agitated, I inform the family of the need to immobilize him and medicate him, as indicated by the deciding physician, so that he can be taken to the hospital, but always restrained. When he is not agitated, dialogue, medication and transferring are enough. What helps a lot is the mingling of the professionals and rapid connection with the regulation and the military police. The family support and rapid referral to the IPQ [Institute of Psychiatry] are also important. Another important thing is to know how to get them not to hurt them and that we should have a better training and even a protocol.

The DCS 3 contains discourses concerning interventions during crisis. The concern of the team about their safety is highlighted when facing the person in crisis, based on the risk that the scene represents for the professional. Concern is part of the professional work, but it should not reinforce the social imagery of the crisis as a madness disease related to aggressiveness. This discourse refers to the need for reflection on the role of the health care professional regarding the care: it is necessary to assess the scene and investigate whether there is any risk to the team; if there is none, the approach and dialogue with the patient and family is performed in order to review the signs and symptoms. It can be inferred that the crisis is the very risk in the scene. For the study the "risk concept in mental health arises from the moment the crisis is warning of the triggering of an alleged mental illness (actual or future)". 22:178 The crisis as a risk is the union of "the urgency for psychiatry, leading to the psychiatric emergency". ${ }^{22: 183}$

The crisis and urgency "are on opposite sides of life. The crisis includes psychosocial aspects, the urgency is determined by the psychiatric vision". 24:183 The crisis turns into urgency from "the moment that directly affects the routine of the 
family (or legal guardian) and when one decides to name the event as such". 22:178 The crisis manifested by the person is the maximum simplification of a relationship in which it is itself reduced to its complex suffering existence to a symptom or behavior that is strange in its way of being in the world. The professional team supports its observation of the symptom so that the response is based on this model of simplification. ${ }^{25}$

As a rule, professional practice for care to the person in crisis reproduces the heritage of the psychiatric hospital, when an act is vested only in the symptom. Denaturalization of action in crisis is necessary by questioning what it is, how it is configured, who defines it, how it manifests itself, and how it should be supported.

When caring for the person in crisis, it is important to read the scene based on how the person's situation is occurring, to establish contacts that consider the participation of the person in crisis in this dialogic relationship. It should be noted that the approach, the willingness of the team to enter a relationship with the person, must recognize her need. It is relevant to mediate the relationship while dealing with conflicts. The relationships should promote meetings with individual responses. Deinstitutionalization of the SAMU staff is necessary, which means that practices should be concrete in the interaction with people, based on their living territory. ${ }^{21}$

Corroborating this area, one study ${ }^{26}$ found the order of priority for the care of people in crisis in emergency departments in Australia, pointing to the prioritization given by regulators in cases of injuries that cause pain and can potentially lead to other health complications, disregarding mental or emotional pain.

Care for the mental health crisis is understood to lack specific team training, sensitizing them to the subjectivity of the subject. Therefore the care for the person in crisis should be based on the team's flexibility to enter a relationship based on listening, the word, in which the person is valued even if the discourse does not make sense to the listener. The resources of the territory, space for life production and subjective person demarcation are considered, provided that they contribute to the alleviation of suffering, in establishing supportive and cooperative care. It should be noted that the team must know what the territory consists of to have more bonds in health care. The management to operationalize the SAMU teams could follow the logic of community health workers who belong to the territory, and who know and have connections with people. To the extent possible, it would be appropriate that the SAMU workers act in health regions where they have territorial bonds.

Prioritizing of controlling interventions is observed in the expression contemplated in the DSC 3: when he is very agitated, I inform the family of the need to immobilize him and medicate him, as indicated by the deciding physician, so that he can be taken to the hospital, but always restrained.

Physical restraint may be needed sometimes. The discrepancy between the caring restraint and the punishing restraint is strongly noted. This conceptual difference is essential to reflect on care after restraint. From the health care professional's perspective, it is desirable to understand that the expression of feelings such as anger, dread and fear are expected when one experiences a crisis situation. It is recommended to respect the "other as a momentarily helpless subject that needs help to regain his integrity. This action can prevent retraction and produce approaches". ${ }^{27: 8-9}$

It should be noted that in any care of a crisis, the name of the person providing care must be stated, and care must be guided not only by the person's name, but mostly by the name that she prefers to be called, which promotes interaction. Family members can be care partners because they live with the person and can indicate strategies for the management of extreme situations with the person. One study, based on Santos' experience of dealing with crises, stresses that decoding the meaning of the experiences contributes to the understanding of crisis, always in a context, because it makes them emerge and enable the relationship of the professional and the person in crisis. This involves the rupture in designing and acting in the preamble of the disease and to find the person in crisis. ${ }^{21}$

The welcoming dialogue is a powerful strategy to be used by the SAMU. This concept means a conversational component at the time of care that seeks to identify, negotiate and meet needs, that can be satisfied in the encounter between the person in crisis and the professional team. In this strategy, there is the possibility of deconstructing the association of psychiatric urgency to aggressiveness and despair. Another possibility would be ethics/care that consists of urgent attention to the person in crisis, care that finds the history, symbolic values, friends, the meaning of the gestures of the person in crisis. ${ }^{22}$ In addition to the forms 
of care for people in crisis, the existence of a 24hour urgency service is a mandatory prerequisite, combined with network services and structured in in the territory. ${ }^{24}$ All these discussions should be guided by permanent educational strategies, designed and agreed upon by the actors involved in the process. ${ }^{28}$

\section{CONCLUSION}

It was evidenced in this study that, despite the change in the public policies in Brazil related to mental health, and the implementation of a new guiding paradigm for thinking about the phenomenon of madness, health care professionals maintain the disease-based and stigmatizing concept as a basis for their care practices, characteristic of classical theories that have endured for centuries in the history of psychiatry. This requires discussion about the phenomenon of "madness" and its forms of treatment/intervention that are closest to the psychosocial paradigm for professional training and in health institutions.

The idea of pre-hospital care as a quick and timely intervention makes it difficult for the teams to perform a more comprehensive action. The interventions are aimed at pre-established, systematized, protocoled strategies, which impair subjective interventions. Thus, they reaffirm the crisis as a simple exacerbation of symptoms that are mainly characterized by risk, which must be controlled and removed at all costs.

For real changes to occur in healthcare practice, it is necessary to overcome the traditional model of psychiatry, revisit the concept of madness in society, and rethink care practices from the psychosocial paradigm and the principles of SUS.

The development of new investigations linked to the person in psychological crisis is suggested from the perspective of the psychosocial paradigm in different care settings.

\section{REFERENCES}

1. Brasil. Portaria n. $2048 / G M, 05$ de novembro de 2002: dispõe sobre o funcionamento dos serviços de urgência e emergência. Brasília (DF): Ministério da Saúde; 2002.

2. Brasil. Portaria n. 1864 /GM de 29 de setembro de 2003. Institui a Política Nacional de Atenção às Urgências, a ser implantada em todas as unidades federadas, respeitadas as competências das três esferas de gestão. Brasília (DF): Ministério da Saúde; 2003.
3. Conselho Federal de Medicina. Resolução CFM n. 1451/95 [online]. Diário Oficial da União, 17 março de 1995 [acesso 2014 Jun 06]. Seção I, p.3666. Disponível em Link: http:/ / www.portalmedico.org. br/resolucoes/cfm/1995/1451_1995.htm

4. Martins MCV, Gois SVT, Barbosa LV, Correa CRG, Guedes SAG. Perfil dos atendimentos psiquiátricos realizados pelo Serviço de Atendimento Móvel de Urgência, Aracaju, janeiro/2010 a fevereiro/2011. Interfaces Científ Saúde Ambiente. 2012; 1:31-9.

5. Pacheco A, Burusco S, Senosiáin MV. Prevalence of processes and pathologies dealt with by the prehospital emergency medical services in Spain. An Sist Sanit Navar. 2010; 33 (Suppl 1):37-46.

6. Silva NC, Nogueira LT. Avaliação de indicadores operacionais obtidos por um Serviço de Atendimento Móvel de Urgência. Cogitare Enferm. 2012; 17(3):471-7.

7. Marques GQ, Lima MADS, Ciconet RM. Conditions treated in the Mobile Medical Emergency Services in Porto Alegre - RS. Acta Paul Enferm. 2012; 24(2):185-91.

8. Santos ACT, Nascimento YCML, Lucena TS, Rodrigues PMS, Brêda MZ, Santos FG. Serviço de Atendimento Móvel de Urgência às urgências e emergências psiquiátricas. Rev enferm UFPE [on line]. 2014 Jun [acesso 2014 Set 28]; 8(6):158696. Disponível em: http://www.revista.ufpe.br/ revistaenfermagem/index.php/revista/article/ view/5946/pdf_5254

9. Jardim KFSB. O serviço ambulatorial móvel de urgência (SAMU) no contexto da reforma psiquiátrica: em análise a experiência de Aracaju/SE [dissertação]. Aracaju: Programa de Pós-graduação em Psicologia, Universidade Federal do Rio Grande do Norte, Natal, 2008.

10. Bonfada D, Guimarães J. Serviço de atendimento móvel de urgência e as urgências psiquiátricas. Psicol Estud. 2012 Abr-Jun; 17(2):227-236.

11. Almeida AB, Nascimento ERP, Rodrigues J, Schweitzer G. Intervenção nas situações de crise psíquica: dificuldades e sugestões de uma equipe de atenção pré-hospitalar. Rev Bras Enferm. 2014 Set-Out; 67(5):708-14.

12. Lefévre F, Lefévre AMC. Pesquisa de representação social: um enfoque quali-quantitativo: a metodologia do Discurso do Sujeito Coletivo. $2^{a}$ ed. Brasília (DF): Liber Livro; 2012.

13. Pereira EC, Costa-Rosa A. Problematizando a reforma psiquiátrica na atualidade: a saúde mental como campo da práxis. Saude Soc. 2012; 21(4):1035-43.

14. Amarante PDC. O homem e a serpente: outras histórias para a loucura e a psiquiatria. $5^{\mathrm{a}}$ ed. Rio de Janeiro (RJ): Editora Fiocruz; 2010.

15. Ferigato SH, Campos RTO, Ballarin MLGS. Atendimento à crise em saúde mental: ampliando conceitos. Rev Psicol UNESP. 2007; 6(1):31-44. 
16. Caplan G. Princípios de psiquiatria preventiva. Rio de Janeiro: Zahar editores; 1980.

17. Silva ATM, Souza JS, Silva CC, Nóbrega MML, Oliveira Filha M, Barros S, et al. Education of nurses in the perspective of the psychiatric reform. Rev Bras Enferm. 2004 Nov-Dez; 57(6):675-8.

18. Waidman MAP, Costa B, Paiano M. Community Health Agents' perceptions and practice in mental health. Rev Esc Enferm USP [online]. 2012 Oct [acess 2012 Feb 27]; 46(5):1170-7. Available from: http:// www.scielo.br/pdf/reeusp/v46n5/en_19.pdf

19. Campos GWS, Amaral MA. A clínica ampliada e compartilhada, a gestão democrática e redes de atenção como referenciais teórico-operacionais para a reforma do hospital. Ciênc Saúde Coletiva. 2007 Jul-Ago; 12(4):849-59.

20. Foucault M. O poder psiquiátrico: curso dado no Collège de France (1973-1974). São Paulo: Martins Fontes; 2006.

21. Nicácio F, Campos GWS. A complexidade da atenção às situações de crise: contribuições da desinstitucionalizaçao para a invenção de práticas inovadora em saúde mental. Rev Ter Ocup Univ São Paulo. 2004 Mai-Ago; 15(2):71-81.

22. Jardim K, Dimenstein M. Risco e crise: pensando os pilares da urgência psiquiátrica. Psicol Rev. 2007 Jun; 13(1):169-90.
23. Costa MS. Construções em torno da crise. Saberes e práticas na atenção em saúde mental e produção de subjetividades. Arq Bras Psicol [online]. 2007 Jun [acesso 2010 Jun 20]; 59(1):94-108. Disponível em: http:/ / pepsic.bvsalud.org/scielo.php?pid=S180952672007000100010\&script=sci_arttext.

24. Häfner H, Rössler W, Haas S. Psychiatric emergency care and crisis intervention: concepts, experiences and results. Psychiatr Prax, 1986 Nov; 13(6):203-12.

25. Dell'acqua G, Mezzina R. Resposta à crise: estratégia e intencionalidade da intervenção no serviço psiquiátrico territorial. In: Amarante $\mathrm{P}$, organizador. Arquivos de saúde mental e atenção psicossocial. Rio de Janeiro: Nau; 2005. p.161-194.

26. Allison M, Kairi K, Keili K, Beverley G, Diego DL. Treatment priority for suicide ideation and behaviours at an Australian emergency department. World J Psychiatry [online]. 2013 Jun [acess 2015 Jun 08]; 3(2):34-40. Available from: www.wjgnet. com/2220-3206/pdf/v3/i2/34.pdf

27. Rodrigues J, Santos SMA, Spricigo JS, Pinho, LB. Uso da criatividade e da tecnologia no ensino da crise em enfermagem psiquiátrica e saúde mental. SMAD. 2010; 6(1):10.

28. Tavares, CMM. A educação permanente da equipe de enfermagem para o cuidado nos serviços de saúde mental. Texto Contexto Enferm. 2006; 15(2):287-95. 